\title{
The role of peers in estimating tenure-performance profiles: Evidence from personnel data
}

Citation for published version (APA):

de Grip, A., Sauermann, J., \& Sieben, I. (2016). The role of peers in estimating tenure-performance profiles: Evidence from personnel data. Journal of Economic Behavior \& Organization, 126, 39-54. https://doi.org/10.1016/j.jebo.2016.03.002

Document status and date:

Published: 01/06/2016

DOI:

10.1016/j.jebo.2016.03.002

Document Version:

Publisher's PDF, also known as Version of record

Document license:

Taverne

Please check the document version of this publication:

- A submitted manuscript is the version of the article upon submission and before peer-review. There can be important differences between the submitted version and the official published version of record.

People interested in the research are advised to contact the author for the final version of the publication, or visit the DOI to the publisher's website.

- The final author version and the galley proof are versions of the publication after peer review.

- The final published version features the final layout of the paper including the volume, issue and page numbers.

Link to publication

\footnotetext{
General rights rights.

- You may freely distribute the URL identifying the publication in the public portal. please follow below link for the End User Agreement:

www.umlib.nl/taverne-license

Take down policy

If you believe that this document breaches copyright please contact us at:

repository@maastrichtuniversity.nl

providing details and we will investigate your claim.
}

Copyright and moral rights for the publications made accessible in the public portal are retained by the authors and/or other copyright owners and it is a condition of accessing publications that users recognise and abide by the legal requirements associated with these

- Users may download and print one copy of any publication from the public portal for the purpose of private study or research.

- You may not further distribute the material or use it for any profit-making activity or commercial gain

If the publication is distributed under the terms of Article $25 \mathrm{fa}$ of the Dutch Copyright Act, indicated by the "Taverne" license above, 


\title{
The role of peers in estimating tenure-performance profiles: Evidence from personnel data ${ }^{\text {is }}$
}

\author{
Andries De Grip ${ }^{\mathrm{a}, \mathrm{b}}$, Jan Sauermann ${ }^{\mathrm{a}, \mathrm{b}, \mathrm{c}, *}$, Inge Sieben ${ }^{\mathrm{a}, \mathrm{d}}$ \\ a Research Centre for Education and the Labour Market (ROA), Maastricht University, Netherlands \\ b Institute for the Study of Labor (IZA), Bonn, Germany \\ c Swedish Institute for Social Research (SOFI), Stockholm University, Sweden \\ d Department of Sociology, Tilburg University, Netherlands
}

\section{A R T I C L E I N F O}

\section{Article history:}

Received 1 April 2015

Received in revised form 12 February 2016

Accepted 10 March 2016

Available online 14 March 2016

\section{JEL classification:}

$\mathrm{J} 24$

D24

L89

Keywords:

Tenure-performance profiles

Peer effects

On-the-job learning

Call centers

\begin{abstract}
A B S T R A C T
This paper investigates how newly hired workers learn on the job and the extent to which this learning is affected by their co-workers' tenure. We estimate tenure-performance profiles using weekly panel data on individual workers' performance. The results show a performance increase of $64 \%$ in the first year of the employment. We show that, during the first three months, workers placed in teams with more experienced peers have significantly steeper tenure-performance profiles than those employed in teams with less experienced peers. Our results suggest that placing new workers in more experienced teams reduces the time new hires need to become equally productive as an experienced worker by $36 \%$, compared to being placed in less experienced teams.
\end{abstract}

(c) 2016 Elsevier B.V. All rights reserved.

\section{Introduction}

Next to investments in formal training, job tenure is shown to be an important determinant of workers' productivity. Previous studies on tenure-performance profiles show that workers experience substantial gains from learning on the job (Bishop, 1989; Kostiuk and Follmann, 1989; Shaw and Lazear, 2008). Data from the international Program for the International Assessment of Adult Competencies (PIAAC) survey show the relevance and high frequency of on-the-job learning at the workplace (OECD, 2013). The percentage of workers who state that they are involved in learning by doing every week ranges from $28 \%$ (South Korea) to $67 \%$ (Spain), with 66\% for workers in the US. Workers, however, might learn not only from

\footnotetext{
is Jan Sauermann gratefully acknowledges financial support from Network Social Innovation (NSI), Maastricht University, and from the Jan Wallanders, Tom Hedelius och Tore Browalds stiftelse (Grant number I2011-0345:1). The authors thank Eric Bonsang, Ben Kriechel, Olivier Marie, Anders Stenberg, and seminar and conference participants at Maastricht University, the Berlin Network of Labor Market Research, Society of Labor Economics, European Association of Labour Economics, and the European Economic Association for helpful comments. This paper has been screened to ensure no confidential information is revealed.

* Corresponding author. Tel.: +46 8162605.

E-mail addresses: a.degrip@maastrichtuniversity.nl (A. De Grip), jan.sauermann@sofi.su.se (J. Sauermann), i.j.p.sieben@uvt.nl (I. Sieben).
} 
practicing their tasks, but also from observing or imitating their peers at work and from peer feedback (Barron et al., 1989). PIACC data suggest that this is not negligible: for the US, 51\% of all workers state that they are involved in learning from co-workers or supervisors on a daily basis. When there are opportunities to learn from peers, a worker's output may thus not only increase with tenure, but also through being exposed to more experienced peers. Although there are various studies of peer effects on worker performance (e.g., Mas and Moretti, 2009; Bandiera et al., 2010), to the best of our knowledge, no studies have analyzed the impact of more experienced peers on the performance of newly hired workers.

We fill this gap in the literature by analyzing tenure-performance profiles using unique data of a large call center that is part of a multinational telephone company in the Netherlands. These personnel data contain detailed information on the performance of individual call agents over time. Over a period of 127 weeks, we observe the individual performance of 284 newly hired agents all performing the same tasks, irrespective of tenure, using the same technology, and facing the same incentives set by the call center's management. This setting provides substantial variation in both tenure and weekly team composition, which allows us to estimate tenure-performance profiles as well as peer effects in learning. The data we use allow for very detailed analyses of tenure-performance profiles. Similar to other studies using comparable data on call center agents (e.g., Castilla, 2005; Liu and Batt, 2007; De Grip and Sauermann, 2012), we use an objective measure of performance that is based on the average call handling time.

We find a large marginal return to tenure in the first months of working for the call center that decreases substantially after gaining experience on the job. This tenure-performance profile closely follows a logarithmic specification. For the first year on the job, a $10 \%$ increase in tenure is related to an increase of $4 \%$ of one standard deviation in performance. This steep learning curve translates into a performance increase of $64 \%$ within the first year of the employment. We show that this effect is not driven by selection of workers out of the firm. Using additional information on customer satisfaction, we find some evidence of a quality-quantity trade-off in the tenure-performance profile. The results suggest, however, that the increase in quantitative performance outweighs the decrease in quality.

As our measure of performance, average handling time, measures how fast workers perform, the data allow us to precisely calculate the firm's investments in new hires. We find that the firm invests, on average, 124 working hours in on-the-job learning of each newly hired worker during the first year. This investment in on-the-job learning is close to the firm's investment in formal training courses during a new hire's first year.

Our results are in line with the results of studies in other sectors of industry that show steep learning in the first period of a new job, after which the rates of learning converge to a level at which further improvements are hardly possible. For example, Carroll et al. (1986) and Kostiuk and Follmann (1989) find that military recruiters show strong performance improvements in the first weeks followed by stable performance. Jovanovic and Nyarko (1995) report similar tenure-performance profiles for several tasks in different industries. More recently, Shaw and Lazear (2008) observed that workers who install car windshields perform $53 \%$ better after eight months of working on the job and even perform $82 \%$ better after one year. ${ }^{1}$ In this study, we provide corroborative evidence for these non-linear learning patterns, provide evidence for several different performance measures, and go beyond previous studies by putting the firm's investments in on-the-job learning in perspective to the firm's investments in formal training courses.

This study also contributes to the literature on peer effects in the workplace. Several studies using information from personnel records find positive externalities either through social ties or through spatial proximity (Bandiera et al., 2010; Falk and Ichino, 2006; Mas and Moretti, 2009; De Grip and Sauermann, 2012). ${ }^{2}$ In contrast to these studies, Guryan et al. (2009) find no significant peer effects on worker performance, suggesting that peer effects might be related to specific industries, occupational groups, or tasks. With respect to peer effects in learning, Barron et al. (1989) provide evidence that workers report to spend a substantial part of learning investments watching other workers performing their tasks, whereas Destré et al. (2008) show that workers can learn about $10 \%$ of their own stock of human capital from their co-workers. In addition, Jackson and Bruegmann (2009) find peer effects among teachers. Students benefit the most if their teacher has more effective colleagues, and this effect is strongest for less experienced teachers. In a study using data from the same call centre, De Grip and Sauermann (2012) analyze the returns to a week-long training program and find that there is a causal effect from treated workers on their untreated peers. This paper contributes to these studies by providing evidence for peer effects on new hires' learning in the first months of the employer-employee relationship.

To estimate peer effects in learning, we exploit the fact that agents are placed in teams of varying peer composition. In the firm analyzed in this study, agents who belong to the same team are located next to each other on the work floor. The assignment of newly hired agents to different teams and the assignment of team members to different working shifts and weeks can be regarded as near-random variation in peer assignment. We exploit this variation to identify peer effects on workers' individual learning processes. We find that there are indeed peer effects when agents work with more experienced peers in their team. While agents in less experienced teams need $160 \mathrm{~h}$ of investments in on-the-job learning to become proficient, those who are placed in more experienced teams need only $102 \mathrm{~h}$. This suggests that placing new agents in experienced teams reduces the investments in on-the-job learning by $36 \%$ during the first year of employment.

\footnotetext{
${ }^{1}$ More broadly, our results also contribute to studies analyzing learning by doing at the establishment level, indicating the learning by doing of individual workers as well as technological or managerial improvements. Examples are aircraft production (Benkard, 2000), wartime ship building (Thompson, 2001), automobile production (Levitt et al., 2013), and cancer surgery (Avdic et al., 2014).

2 Herbst and Mas (2015) provide an excellent overview of laboratory and field studies on peer effects in the workplace.
} 
The paper is structured as follows. In Section 2, we describe the setting of this study and present arguments for both learning by doing and learning from others. In Section 3, we discuss our empirical model and present the estimates of the tenure-performance profile of call agents and the effects of peers on workers' tenure-performance profiles. We then provide more evidence on the identification of our results and present additional results using alternative performance measures in Section 4. Section 5 summarizes and concludes the study.

\section{Data}

\subsection{Information on the workplace}

To estimate tenure-performance profiles and the impact of peers on the shape of these profiles, we use panel data of call agents in a call center with weekly performance information. The call center belongs to a multinational telecommunications company in the Netherlands and acts as a service center for the firm's current and prospective customers (cf. De Grip and Sauermann, 2012). To ensure a homogeneous production process, we focus our analysis on the largest department in the call center, which handles the inbound calls of private customers with fixed cell phone contracts. All agents working in this department have the same task of handling customer calls in case of questions, complaints, or problems. Other interactions with customers, such as written correspondence, are dealt with by other back-office employees.

In case of vacancies, a temporary work agency selects applicants and employs them as temporary help agents, after which they are hired under fixed-term contracts by the call center. Prior to their first working week, new agents receive an initial training of about three weeks. The department consists of 16 teams, with an average team size of 15 agents. Each of the teams is led by a team leader who is responsible for monitoring and coaching the agents on the team. In general, all teams provide all services; that is, there is no specialization of teams in handling certain types of calls or serving certain types of customers. Team leaders are not involved in the selection of agents to their team. Instead, the department's general management assigns newly hired and trained agents to teams with vacancies.

Although agents' performance is continuously measured, they are paid a flat pay with a yearly adjustment. After a formal evaluation by the team leader following an annual appraisal interview, agents can receive a wage increase of up to $8 \%$, as well as an annual bonus, both of which depend on the grade obtained in the appraisal interview. The grade is supposed to reflect the agents' performance as well as their behavior toward co-workers and management.

\subsection{Measuring performance}

The data contain objective performance information for each call agent for each week the agent works. The performance measure $y_{i, t}$ is based on the average handling time $a h t_{i, t}$ of agent $i$ in calendar week $t$. It measures the average time an agent spent talking to a customer and logging the information about the call in the customer database. This measure has the advantage of being an automatically generated key performance indicator of the call center and is not affected by supervisors' potentially subjective performance evaluations (Flabbi and Ichino, 2001). Furthermore, this measure is preferable to wage data because it directly measures performance, while agents' wages are fixed under hourly pay (Shaw and Lazear, 2008).

In recent studies using data on call agents, similar outcomes are used to measure an agent's productivity (e.g., Castilla, 2005; Liu and Batt, 2007; De Grip and Sauermann, 2012). Average handling time is used by management as the key performance indicator for monitoring the call center's performance to reduce costs by decreasing the average agent's handling time without decreasing quality and is measured in seconds. We therefore define productivity as $y_{i, t}=\left(100 / a h t_{i, t}\right)$. A decrease in the average handling time $a h t_{i, t}$ is thus interpreted as an increase in performance $y_{i, t}{ }^{3}$

\subsection{Potential for peer effects}

Irrespective of tenure, all agents have the same task, that is, answering customer calls. If new hires are exposed to peers with higher tenure in the early days of their employment in the firm, they may learn from their peers in different ways, such as effectively retrieving information from customers or how to use the computer software system in specific cases. This allows them to deal with customers' requests more efficiently.

We argue that these peer effects are strongest within teams. First, workplaces in the call center are organized into work islands, with up to eight agents of a team sitting next to each other. This spatial proximity implies that there is potential for peer effects through learning from peers by exchanging information and giving feedback. As there are no dividing walls between individual work places, agents can, for example, learn through observing their peers, through asking their peers during calls, or through getting feedback either between calls or during breaks. Second, agents of a team participate in regular team meetings. A total of $80 \%$ of the agents stated that they exchange work-related information mostly during official team meetings or at their workplace (De Grip and Sauermann, 2012). More experienced workers are also encouraged to help their co-workers as the grade they get in their annual appraisal interview also depends on their "behavior towards

\footnotetext{
3 We deal with potential quality-quantity trade-offs in Section 4.2 .
} 
Table 1

Descriptive statistics

\begin{tabular}{|c|c|c|c|c|c|}
\hline & $\begin{array}{l}\text { (1) } \\
\text { All agents }\end{array}$ & $\begin{array}{l}(2) \\
\text { New hires }\end{array}$ & $\begin{array}{l}(3) \\
\text { Stayer }\end{array}$ & $\begin{array}{l}(4) \\
\text { Leaver }\end{array}$ & $\begin{array}{l}(5) \\
\operatorname{Diff}(3)-(4)\end{array}$ \\
\hline Performance $\left(y_{i, t}\right)$ & $\begin{array}{l}0.3465 \\
(0.1581)\end{array}$ & $\begin{array}{l}0.3032 \\
(0.1037)\end{array}$ & $\begin{array}{l}0.3179 \\
(0.1035)\end{array}$ & $\begin{array}{l}0.2892 \\
(0.1021)\end{array}$ & $\begin{array}{l}0.0287^{* * *} \\
(11.0674)\end{array}$ \\
\hline Call quality $\left(y_{i, t}^{q}\right)^{\S}$ & $\begin{array}{l}0.4998 \\
(0.1930)\end{array}$ & $\begin{array}{l}0.5270 \\
(0.2032)\end{array}$ & $\begin{array}{l}0.5202 \\
(0.1959)\end{array}$ & $\begin{array}{l}0.5337 \\
(0.2101)\end{array}$ & $\begin{array}{l}-0.0135^{*} \\
(-2.2648)\end{array}$ \\
\hline Composite measure $\left(y_{i, t}^{\prime}\right)^{\S}$ & $\begin{array}{l}0.2667 \\
(0.0819)\end{array}$ & $\begin{array}{l}0.2382 \\
(0.0728)\end{array}$ & $\begin{array}{l}0.2465 \\
(0.0689)\end{array}$ & $\begin{array}{l}0.2299 \\
(0.0756)\end{array}$ & $\begin{array}{l}0.0166^{* * * *} \\
(7.7792)\end{array}$ \\
\hline Grade $1^{\S}$ & $\begin{array}{l}6.8176 \\
(1.8739)\end{array}$ & $\begin{array}{l}6.9222 \\
(1.9244)\end{array}$ & $\begin{array}{l}7.1152 \\
(1.7746)\end{array}$ & $\begin{array}{l}6.6407 \\
(2.0989)\end{array}$ & $\begin{array}{l}0.4745^{*} \\
(2.2764)\end{array}$ \\
\hline Grade $2^{\S}$ & $\begin{array}{l}6.3362 \\
(1.9960)\end{array}$ & $\begin{array}{l}6.4277 \\
(2.0795)\end{array}$ & $\begin{array}{l}6.6068 \\
(2.0291)\end{array}$ & $\begin{array}{l}6.1604 \\
(2.1318)\end{array}$ & $\begin{array}{l}0.4464^{*} \\
(1.9738)\end{array}$ \\
\hline Grade $3^{\S}$ & $\begin{array}{l}5.8859 \\
(2.3542)\end{array}$ & $\begin{array}{l}6.0102 \\
(2.3803)\end{array}$ & $\begin{array}{l}6.1440 \\
(2.2583)\end{array}$ & $\begin{array}{l}5.8237 \\
(2.5372)\end{array}$ & $\begin{array}{l}0.3202 \\
(1.2025)\end{array}$ \\
\hline Tenure (in years) & $\begin{array}{l}2.7514 \\
(3.5988)\end{array}$ & $\begin{array}{l}0.3296 \\
(0.2535)\end{array}$ & $\begin{array}{l}0.4035 \\
(0.2794)\end{array}$ & $\begin{array}{l}0.2590 \\
(0.2023)\end{array}$ & $\begin{array}{l}0.1445^{* * *} \\
(23.5785)\end{array}$ \\
\hline Working hours & $\begin{array}{l}20.5103 \\
(9.9938)\end{array}$ & $\begin{array}{l}23.7400 \\
(10.2536)\end{array}$ & $\begin{array}{l}25.3378 \\
(11.0127)\end{array}$ & $\begin{array}{l}22.2122 \\
(9.2173)\end{array}$ & $\begin{array}{l}3.1256^{* * *} \\
(12.23)\end{array}$ \\
\hline Training hours (per week) ${ }^{\S}$ & $\begin{array}{l}0.8749 \\
(4.8540)\end{array}$ & $\begin{array}{l}1.0342 \\
(5.1884)\end{array}$ & $\begin{array}{l}1.0076 \\
(5.1193)\end{array}$ & $\begin{array}{l}1.0595 \\
(5.2542)\end{array}$ & $\begin{array}{l}-0.0519 \\
(-0.3965)\end{array}$ \\
\hline Gender ( 1 = male $)$ & $\begin{array}{l}0.2938 \\
(0.4555)\end{array}$ & $\begin{array}{l}0.3352 \\
(0.4721)\end{array}$ & $\begin{array}{l}0.3442 \\
(0.4752)\end{array}$ & $\begin{array}{l}0.3266 \\
(0.4690)\end{array}$ & $\begin{array}{l}0.0176 \\
(1.4759)\end{array}$ \\
\hline Age $^{\S}$ & $\begin{array}{l}32.5582 \\
(11.1813)\end{array}$ & $\begin{array}{l}26.2018 \\
(7.9377)\end{array}$ & $\begin{array}{l}26.9163 \\
(9.0759)\end{array}$ & $\begin{array}{l}25.4655 \\
(6.4808)\end{array}$ & $\begin{array}{l}1.4508^{* * *} \\
(7.0521)\end{array}$ \\
\hline Educational level§ & $\begin{array}{l}2.0669 \\
(0.7981)\end{array}$ & $\begin{array}{l}1.9897 \\
(0.7226)\end{array}$ & $\begin{array}{l}1.8899 \\
(0.7266)\end{array}$ & $\begin{array}{l}2.2890 \\
(0.6211)\end{array}$ & $\begin{array}{l}-0.3991^{* * *} \\
(-11.6259)\end{array}$ \\
\hline Observations & 14,832 & 6295 & 3077 & 3218 & 6295 \\
\hline Number of agents & 407 & 284 & 98 & 186 & 284 \\
\hline
\end{tabular}

Note: ${ }^{*} p<0.10,{ }^{* *} p<0.05,{ }^{* * *} p<0.01$. The sample of new hires (estimation sample) is defined as all agents with a maximum tenure of one year who can be observed from their first working week (new hires). Variables marked with a "§" are available for subsamples only. Standard deviations are in parentheses.

co-workers". They also do not have an incentive not to help new hires as there are no bonuses allocated on the basis of measured productivity. Moreover, since there is no hierarchy within the team, there is no competition between workers for particular (senior) positions.

This indicates that there is potential for peer effects in this production process and that these effects are likely to be larger within teams than between teams. In this study, we exploit the assignment of individual agents to teams. This generates near-random variation in the teammates an agent works with and thus in exposure to peer tenure.

\subsection{Sample selection and descriptive statistics}

We observe all agents working for this department and their performance for each week from October 2007 through March 2010. In the course of the observation period, 407 agents worked for this department. We focus our analysis on the sample of new hires in their first year. We define new hires as agents we can observe from their first working week. This avoids left-censoring the data and lowers the risk of biased results due to selection out of the firm. Furthermore, learning is likely to be concentrated in the beginning of the employment relations and more affected by tenure in this period compared to later periods (cf. Shaw and Lazear, 2008).

The estimation sample of the newly hired comprises 284 agents, for a total of 6295 observations. Table 1 shows the descriptive statistics for all agents (Column (1)) and the agents in the estimation sample (Column (2)). Because of the focus on those newly hired, agents in the estimation sample have substantially lower tenure ( 2.8 years in the full sample versus 0.3 years in the estimation sample). This translates into large differences in performance $y_{i, t}$. Agents in the full sample have an average performance of 0.35 , while agents in the estimation sample have an average performance of 0.3 . The average number of working hours is $21 \mathrm{~h}$ per week for the average agent, while agents in the estimation sample work $24 \mathrm{~h}$ per week. A total of $29 \%$ (34\%) of the agents in the full (estimation) sample are men and their average age is 33 (26) years. These figures are comparable to those of call centers in general, which are characterized by a predominantly female workforce with a substantial proportion of part-time workers (Batt et al., 2009).

\section{Estimating tenure-performance profiles}

\subsection{Theoretical framework}

Our theoretical framework follows the model of Rosen (1972), in which individuals enter jobs with an initial stock of human capital $\left(h_{0}\right)$, for example, from schooling or previous jobs. Workers can gain additional human capital by investing in 
(a)

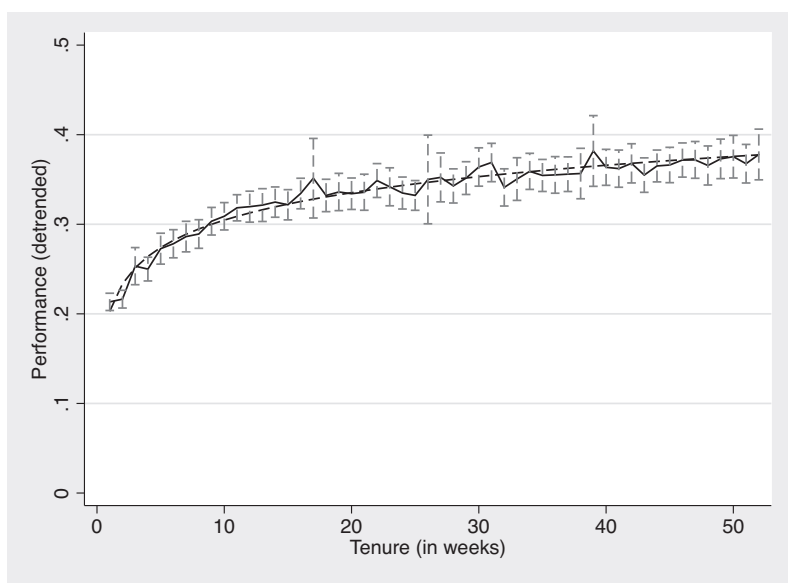

(b)

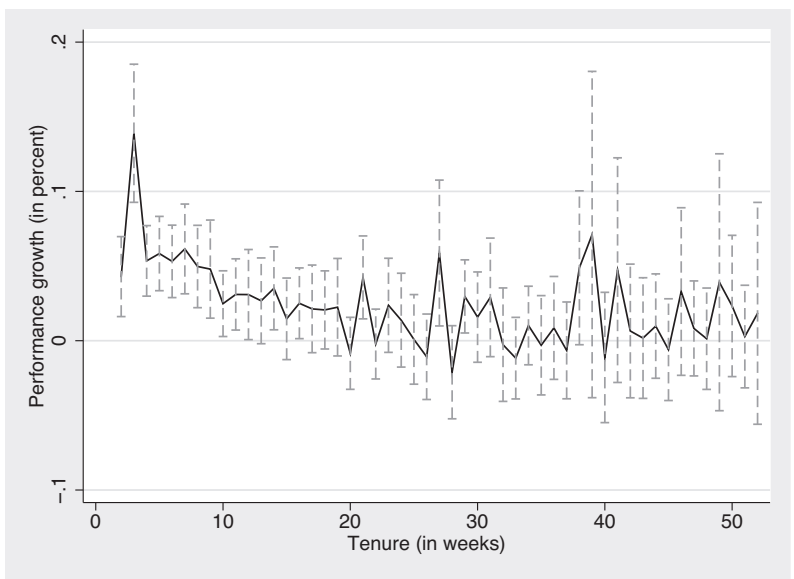

Fig. 1. Tenure-performance profiles and performance growth among new hires. Note: The solid line in Panel (a) shows the mean of $y_{i, t}$ by tenure for new hires. The underlying measure of performance is detrended by including week fixed effects. The capped spikes show the appropriate $95 \%$ confidence intervals. The dashed line shows the predicted performance from a regression of $y_{i, t}$ on $\log$ (tenure). The solid line in Panel (b) shows the growth of the detrended performance measure by tenure with corresponding confidence intervals.

on-the-job learning. On-the-job learning comes at opportunity costs, but positively affects the worker's job-specific human capital in subsequent periods $t, h_{t}$. In Rosen (1972), workers' investments decline with tenure, since there is less time available to capitalize the returns from later investments. The growth rate of human capital from period $t-1$ to $t$ is denoted $g_{t}$ :

$$
h_{t}-h_{t-1}=g_{t} \cdot h_{t-1}
$$

The more experienced workers get, the closer they come to the maximum of on the job knowledge that they can accumulate in this job. Rosen's model implies that workers exhibit strong growth rates in $h_{t}$ in their early career that later diminish $\left(h^{\prime}>0\right.$ and $\left.h^{\prime \prime}<0\right)$.

While the rate of learning $g_{t}$ is likely to be determined by past investments in self-learning, previous studies provide evidence of peer effects in learning (Destré et al., 2008; Jackson and Bruegmann, 2009; De Grip and Sauermann, 2012). If workers with higher tenure have higher levels of knowledge, workers who work with them should be more prone to learn from them. For the purpose of this study, we therefore split learning into two components: learning by doing (i.e., self-learning) and learning from others. The term $g_{t} \cdot h_{t-1}$ is therefore replaced by $g_{t} \cdot h_{i, t-1}$, which captures self-learning, or learning by doing, and $g_{j,(i), t} \cdot h_{j,(i), t-1}$, which captures learning from peers in a worker $i$ 's team $j$ :

$$
h_{t}-h_{t-1}=g_{i, t} \cdot h_{i, t-1}+g_{j,(i), t} \cdot h_{j,(i), t-1}
$$

The parameter $g_{i, t}$ captures self-learning, while the parameter $g_{j,(i), t}$ captures learning from a peer's tenure.

\subsection{Estimating learning effects}

We first present evidence on workers' learning by doing. The solid line in Panel (a) of Fig. 1 shows the average performance of all new hires over tenure in their first year working for the call center. The figure shows a steep performance increase in the early weeks of an agent's tenure that then flattens substantially. New hires perform $48 \%$ better after six months of tenure compared with average performance in the first month of employment. After one year, agents perform about $64 \%$ better.

To quantify learning by doing, we first estimate tenure-performance profiles using a linear-log specification. The dashed line in Panel (a) of Fig. 1, which shows the predicted performance from a regression of $y_{i, t}$ on the logarithm of tenure $d_{i, t}$, $\log \left(d_{i, t}\right)$, follows average performance (solid line) remarkably closely. This suggests that the linear-log specification is suitable to estimate the effect of tenure $\log \left(d_{i, t}\right)$ on performance $y_{i, t}$. Our regression model can thus be written as

$$
y_{i, t}=\alpha+\log \left(d_{i, t}\right)^{\prime} \beta_{1}+X_{i, t}^{\prime} \beta_{2}+\gamma_{t}+u_{i, t}
$$

where $\alpha$ is the constant, $X_{i, t}$ contains various individual-specific characteristics (e.g., working hours), team fixed effects, and week fixed effects $\gamma_{t}$ to control for time trends and fluctuations. ${ }^{4}$ The idiosyncratic error term $u_{i, t}$ is clustered to allow for within-agent correlation.

\footnotetext{
${ }^{4}$ Average performance fluctuates substantially around its mean due to issues such as technical network problems, problems with the internal IT system, and changes in the composition of call types. Time fixed effects $\gamma_{t}$ are introduced to control for these shocks.
} 
Table 2

The effect of tenure on the performance of new hires.

\begin{tabular}{|c|c|c|c|c|c|c|c|c|c|}
\hline & $(1)$ & $(2)$ & (3) & $(4)$ & $(5)$ & (6) & $(7)$ & $(8)$ & (9) \\
\hline $\log ($ tenure $)$ & $\begin{array}{l}0.0475^{* * *} \\
(0.0026)\end{array}$ & $\begin{array}{l}0.0455^{\text {*** }} \\
(0.0026)\end{array}$ & $\begin{array}{l}0.0402^{* * *} \\
(0.0034)\end{array}$ & $\begin{array}{l}0.0381^{* * *} \\
(0.0038)\end{array}$ & $\begin{array}{l}0.0393^{* * *} \\
(0.0032)\end{array}$ & $\begin{array}{l}0.0358^{* * *} \\
(0.0038)\end{array}$ & $\begin{array}{l}0.0445^{* * *} \\
(0.0024)\end{array}$ & $\begin{array}{l}0.0443^{* * *} \\
(0.0035)\end{array}$ & $\begin{array}{l}0.0437^{* * * *} \\
(0.0033)\end{array}$ \\
\hline Working hours & & & $\begin{array}{l}-0.0004 \\
(0.0003)\end{array}$ & $\begin{array}{l}0.0001 \\
(0.0004)\end{array}$ & $\begin{array}{l}-0.0004 \\
(0.0003)\end{array}$ & $\begin{array}{l}0.0000 \\
(0.0004)\end{array}$ & $\begin{array}{l}-0.0008^{* * *} \\
(0.0002)\end{array}$ & $\begin{array}{l}-0.0003 \\
(0.0002)\end{array}$ & $\begin{array}{l}-0.0002 \\
(0.0002)\end{array}$ \\
\hline Training hours (cumulated) & & & $\begin{array}{l}0.0007^{* *} \\
(0.0003)\end{array}$ & $\begin{array}{l}0.0008^{* *} \\
(0.0003)\end{array}$ & $\begin{array}{l}0.0006^{* *} \\
(0.0003)\end{array}$ & $\begin{array}{l}0.0007^{* *} \\
(0.0003)\end{array}$ & $\begin{array}{l}-0.0001 \\
(0.0002)\end{array}$ & $\begin{array}{l}0.0002^{*} \\
(0.0001)\end{array}$ & \\
\hline Gender $(1=$ male $)$ & & $\begin{array}{l}-0.0017 \\
(0.0088)\end{array}$ & $\begin{array}{l}-0.0009 \\
(0.0091)\end{array}$ & $\begin{array}{l}-0.0010 \\
(0.0090)\end{array}$ & $\begin{array}{l}0.0001 \\
(0.0093)\end{array}$ & $\begin{array}{l}0.0001 \\
(0.0092)\end{array}$ & & & \\
\hline Age & & $\begin{array}{l}-0.0009 \\
(0.0007)\end{array}$ & $\begin{array}{l}-0.0011 \\
(0.0008)\end{array}$ & $\begin{array}{l}-0.0011 \\
(0.0008)\end{array}$ & $\begin{array}{l}-0.0012^{*} \\
(0.0007)\end{array}$ & $\begin{array}{l}-0.0012^{*} \\
(0.0007)\end{array}$ & & & \\
\hline Constant & $\begin{array}{l}0.3743^{* * *} \\
(0.0074)\end{array}$ & $\begin{array}{l}0.3973^{* * *} \\
(0.0205)\end{array}$ & $\begin{array}{l}0.3962^{* * *} \\
(0.0252)\end{array}$ & $\begin{array}{l}0.3698^{* * *} \\
(0.0336)\end{array}$ & $\begin{array}{l}0.3978^{* * *} \\
(0.0293)\end{array}$ & $\begin{array}{l}0.3231^{* * * *} \\
(0.0406)\end{array}$ & $\begin{array}{l}0.3905^{* * *} \\
(0.0077)\end{array}$ & $\begin{array}{l}0.3923^{* * *} \\
(0.0326)\end{array}$ & $\begin{array}{l}0.4102^{* * *} \\
(0.0323)\end{array}$ \\
\hline$R^{2}$ & 0.206 & 0.195 & 0.208 & 0.289 & 0.233 & 0.311 & 0.230 & 0.359 & 0.371 \\
\hline Observations & 6295 & 5907 & 5551 & 5551 & 5551 & 5551 & 5551 & 5551 & 6295 \\
\hline Number of agents & 284 & 263 & 228 & 228 & 228 & 228 & 228 & 228 & 284 \\
\hline Individual fixed effects & No & No & No & No & No & No & Yes & Yes & Yes \\
\hline Week fixed effects & No & No & No & Yes & No & Yes & No & Yes & Yes \\
\hline Team fixed effects & No & No & No & No & Yes & Yes & No & Yes & Yes \\
\hline
\end{tabular}

Note: ${ }^{*} p<0.10,{ }^{* *} p<0.05,{ }^{* * *} p<0.01$. Dependent variable: $y_{i, t}$. All regressions are estimated using all new hires. Standard errors are clustered at the agent level.

Our parameter of interest is $\beta_{1}$. The estimated parameter determines the slope of the tenure-performance profile, which indicates the learning process of new hires. Because agents start at different points in time, the effect of tenure can be identified from time effects. ${ }^{5}$

Table 2 shows the results of estimating different specifications of Eq. (3) with varying control variables and varying sets of fixed effects. Across these specifications, we estimate $\widehat{\beta}_{1}$ between 0.0358 and 0.0475 . This means that a $10 \%$ increase in tenure is related to an increase in an agent's performance $y_{i, t}$ of roughly 0.004 . Given a standard deviation of 0.1037 , this translates into an increase of about $4 \%$ of one standard deviation of performance $y_{i, t}$.

To control for agents' characteristics, we include weekly working hours, the number of training hours, and the agents' gender and age. The inclusion of working hours and the number of hours of in-house training programs cumulated over the agent's tenure slightly reduces the estimated tenure coefficient to 0.0402 (Column (3) in Table 2 ). ${ }^{6}$ As the tenure coefficient $\left(\widehat{\beta}_{1}\right)$ is expected to include the results of both on-the-job learning and formal training, the estimated effect of tenure is indeed lower when controlling for formal training courses.

In Column (4), we include week fixed effects to control for week-specific changes in performance, while in Column (5) team fixed effects control for unobserved heterogeneity between teams such as team leader-specific effects. The estimation results reported in Column (6) show the estimates with both team and week fixed effects. Neither substantially alters the estimated effect of tenure on performance. As a last step, we include individual fixed effects (Columns (7)-(9)). Worker fixed effects are included to control for time-invariant unobservable characteristics that affect both worker tenure and performance (Altonji and Shakotko, 1987). Contrary to the usual finding of a lower tenure coefficient with individual fixed effects, the estimates in Columns (7)-(9) are larger than for the same regressions without individual fixed effects. A plausible explanation for this result is that we only observe a very steep performance increase in the first months of employment for leavers, whereas we observe declining performance growth in later months of employment only for those who stay. We find that if we limit the sample to the first three or six months of tenure, the estimates behave as expected: The inclusion of individual fixed effects leads to a significantly lower coefficient for log(tenure). This is opposite to the estimates presented in Table 2 and is likely due to the fact that we do not observe the flattening of the tenure-performance profile for agents leaving the call center. ${ }^{7}$ For the remainder of this paper, we use the specification presented in Column (6) of Table 2 as this is the most conservative estimate of the tenure-performance profile.

We interpret the tenure-performance profile as learning in the workplace. Repetition of the same task, that is, answering customer calls, leads to rapid performance improvements in the first months of employment, with decreasing returns to tenure. Panel (b) of Fig. 1 shows the growth rate of performance for each week of tenure. Growth rates seem to converge to a low level after only a few weeks of tenure. This suggests that the initial learning potential is large, whereas performance improvement thereafter is rather small. Yet, there might be two alternative explanations. First, the tenure-performance profile might be the result of incentives. The steep increase in performance during the first months of employment is,

\footnotetext{
5 Models using linear, quadratic, and cubic specifications of tenure yield stable results irrespective of the inclusion of weekly or individual worker fixed effects.

6 Examples of formal in-house training are instructions for promotions or training courses on how to handle customers more efficiently.

7 We do not report these results in the interest of brevity, but they are available upon request.
} 


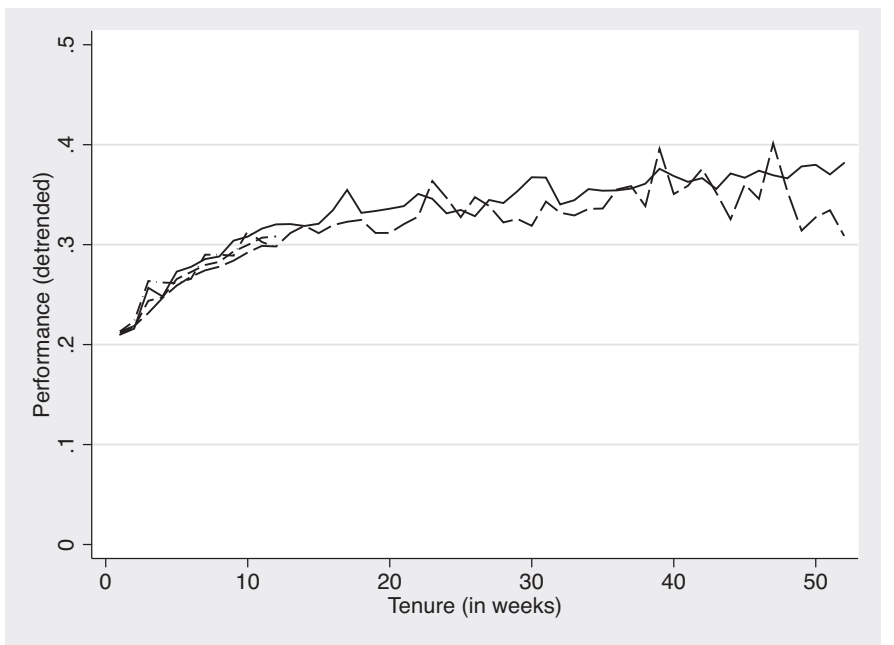

Fig. 2. Tenure-performance profiles for stayers and leavers. Note: This figure shows the tenure-performance profiles for agents staying 12 months or longer (solid line), agents who are staying for at least 3 months but are leaving within the first 12 months (long dashed line), agents staying for at least 3 months (short dashed line), and agents leaving within the first three months (dashed-dotted line).

however, not reflected by an increase in worker pay. Since workers' wages are adjusted only once each year, there are no explicit incentives that can explain this steep tenure-performance profile.

The second alternative interpretation for our findings is that the selection of agents might be linked to unobserved factors such as motivation or ability. Indeed, call centers face a relatively high worker turnover compared to other industry sectors (Batt et al., 2006). A total of $66 \%$ of all newly hired agents (186 agents) observed in our data leave the department within the first year. A large share of these agents (76\%) leave the department within six months ("leavers"). If the probability to quit is related to individual performance or to unobserved factors that affect both the tenure and performance of an individual worker (such as the worker's ability), the shape of the estimated tenure-performance profile is likely to be affected by workers who quit the firm. The observed increase in performance with tenure could thus be partly due to improved match quality instead of on-the-job learning. Columns (3)-(5) of Table 1 show that leavers have lower performance, work on average fewer hours, are younger, and have higher completed education, compared to agents who stay in the department throughout our data. ${ }^{8}$

To further investigate whether labor turnover is selective, we first provide descriptive evidence in Fig. 2. The figure shows the tenure-performance profile for agents staying in the department throughout their first year (solid line) and agents leaving within the first 12 months (dashed line). Though the tenure-performance profiles for 12 months-leavers seems to be slightly lower than the one for 12 months-stayers, all profiles are remarkably close to each other. Individuals leaving shortly, i.e. within three months, after entering the department provide similar performance as agents staying longer in the department. Though one might argue that this might be a net effect of negative selection (out of the firm) and positive selection (to other departments in the firm), this figure suggests that selection effects are less relevant.

This result is also confirmed by the results in Table 3. Columns (1) and (2) show the estimated tenure-performance profiles for agents who stay for at least three months (Column (1)), while Column (2) shows the results for agents who drop out during this period. The results show that the stayers have a significantly higher tenure-performance profile compared to the leavers. However, when looking at agents who survived at least three months (Columns (3) and (4)), we observe no significant difference in the estimated tenure-performance profiles for the two groups. This suggests that selection only occurs in the first few months of working for the call center.

Previous studies also report quite large estimates of on-the-job learning in other occupations, with strong learning effects in the early period of job tenure that then flattens, most likely depending on the complexity of the tasks. Carroll et al. (1986) find a roughly $350 \%$ performance increase in the first year for Navy recruiters. In their study, the size of this effect is, however, driven by a very low productivity in the first month. For several jobs, Jovanovic and Nyarko (1995) report similar strong learning that is comparable to the results of our study. Shaw and Lazear (2008) report that windshield installers improve performance in the first six (12) months by 53\% (82\%). The main reason for differences in estimated tenure-performance profiles across studies is probably the potential to learn on the job, as well as the availability of alternative learning routes, such as vocational education and vocational training, which vary between industry sectors and occupational groups. ${ }^{9}$ If

\footnotetext{
${ }^{8}$ Agents leaving the call center department are defined as agents who disappear from the personnel data for at least 20 consecutive weeks and do not reappear. These drop-outs may be internal, that is, leaving for similar or other jobs in other departments, or external, that is, leaving the firm entirely.

9 Another reason for differences in performance increases during the first period of employment in different studies is likely to be the definition of tenure. In our study, tenure is defined in calendar weeks, starting with week 1 as the first working week after the initial training at the firm. Using data that are
} 
Table 3

Estimating tenure-performance profiles for stayers and leavers.

\begin{tabular}{|c|c|c|c|c|}
\hline & $\begin{array}{l}(1) \\
\text { Stayer } \\
3 \text { months }\end{array}$ & $\begin{array}{l}(2) \\
\text { Leaver } \\
3 \text { months }\end{array}$ & $\begin{array}{l}(3) \\
\text { Stayer } \\
12 \text { months }\end{array}$ & $\begin{array}{l}(4) \\
\text { Leaver } \\
12 \text { months }\end{array}$ \\
\hline $\log ($ tenure $)$ & $\begin{array}{l}0.0457^{* * *} \\
(0.0059)\end{array}$ & $\begin{array}{l}0.0321^{* * *} \\
(0.0047)\end{array}$ & $\begin{array}{l}0.0311^{* * *} \\
(0.0065)\end{array}$ & $\begin{array}{l}0.0316^{* * *} \\
(0.0044)\end{array}$ \\
\hline Constant & $\begin{array}{l}0.4834^{* * *} \\
(0.0572)\end{array}$ & $\begin{array}{l}0.5044^{* * *} \\
(0.0341)\end{array}$ & $\begin{array}{l}0.1998^{* * *} \\
(0.0509)\end{array}$ & $\begin{array}{l}0.3069 * * * \\
(0.0440)\end{array}$ \\
\hline$R^{2}$ & 0.388 & 0.484 & 0.332 & 0.372 \\
\hline Observations & 1135 & 1408 & 2970 & 2210 \\
\hline Number of agents & 95 & 133 & 95 & 83 \\
\hline
\end{tabular}

Note: ${ }^{*} p<0.10,{ }^{* *} p<0.05,{ }^{* * *} p<0.01$. Dependent variable: $y_{i, t}$. All regressions are estimated using all new hires. Standard errors are clustered at the agent level. Columns (1) and (2) include observations from the first 3 months of tenure; Columns ( 3 ) and (4) include observations from the first 12 months of tenure. All regressions include week fixed effects, team fixed effects, and control variables (working hours, cumulated training hours, gender, and age).

vocational learning and learning on the job are substitutes, prior investments in training will be negatively related to the amount of on-the-job learning.

\subsection{Estimating peer effects in learning}

The steep tenure-performance profile for newly hired agents raises the question to what extent they learn from peers in their team $j$. Our main variable to capture peer effects, denoted $\bar{d}_{j,(i), t}$, is based on the measure of peer tenure, which is defined as the average tenure of an agent $i$ 's peer in the same team $j$ in the week $t$, excluding the agent $i$ 's own contribution ${ }^{10}$ :

$$
\bar{d}_{j,(i), t}=\frac{\sum_{k=1}^{K_{j, t}} d_{k, t}-d_{i, t}}{K_{j, t}-1}
$$

where $K_{j, t}$ is the total number of agents in an agent's team $j$ in week $t$. Because not every agent is working in each week, team size $K_{j, t}$ can vary from week to week. For providing evidence on peer effects, we calculate this variable for average tenure of current peers, average tenure of last week's peers, and the average of peer tenure during the last 4 weeks. In either definition, agent $i$ 's own contribution to the team $j$ 's mean is excluded from the calculation of average peer tenure (Angrist, 2014).

Fig. 3 shows the tenure-performance profile for agents with peer tenure below (solid line) and above (dashed line) the median peer tenure $\left(\bar{d}_{j,(i), t}\right)$. The figure shows that agents who are employed in relatively experienced teams appear to have slightly higher tenure-performance profiles and thus experience faster learning.

As a test of peer effects in learning, we augment Eq. (3) by a linear variable measuring average peer tenure in the team in which they are employed $\left(\bar{d}_{j,(i), t}\right)$ :

$$
y_{i, t}=\alpha+\log \left(d_{i, t}\right)^{\prime} \beta_{1}+X_{i, t}^{\prime} \beta_{2}+\bar{d}_{j,(i), t} \beta_{3}+\gamma_{t}+u_{i, t}
$$

Columns (1)-(3) of Table 4 shows estimation results of the effect of current, last week's, and last month's average peer tenure, on the main measure of performance, $y_{i, t}$. These results indicate that average tenure of peers does not significantly affect new hires' performance. The point estimates of peer tenure in all regressions are in the same range (0.0033-0.0044), yet all not significantly different from zero.

Although peer effects are often defined as averages across groups, the linear peer tenure variable assuming constant effects throughout the first year of employment might not be a good approximation to estimate learning effects as the previous subsection provided evidence that learning of agents is particularly steep in the very early months, but decreasing thereafter. Therefore, we estimate tenure-performance profiles (Eq. (3)) separately for agents who are exposed to peers with above-median tenure, and for agents who are exposed to below-median tenure, respectively. This does not only relax the assumption of a linear effect of average peer tenure, but also allows for differences of the curvature of the tenureperformance profile between agents placed in low-tenure and high-tenure teams. This model is estimated for the first 3,6 , 9 , and 12 months of tenure, respectively.

The results, shown in Table 5, provide evidence for differences in tenure-performance profiles between agents placed in teams with low-tenure peers, and agents placed in teams high-tenure teams. Whereas the point estimate for tenureperformance profiles in high-tenure teams is larger for all periods, the estimates are only significantly different during new hires' first three months of tenure (Columns (1) and (2)). During this period, agents placed in teams with peers with

\footnotetext{
aggregated, for example, at the month level yields different estimates. Estimates of tenure-performance profiles will therefore not be perfectly comparable across studies.

10 By measuring peer effects by average peer tenure instead of average performance, we avoid the problem of spurious correlation, which can appear if both the left-hand side variable and the peer variable are based on the same variable (Angrist, 2014).
} 


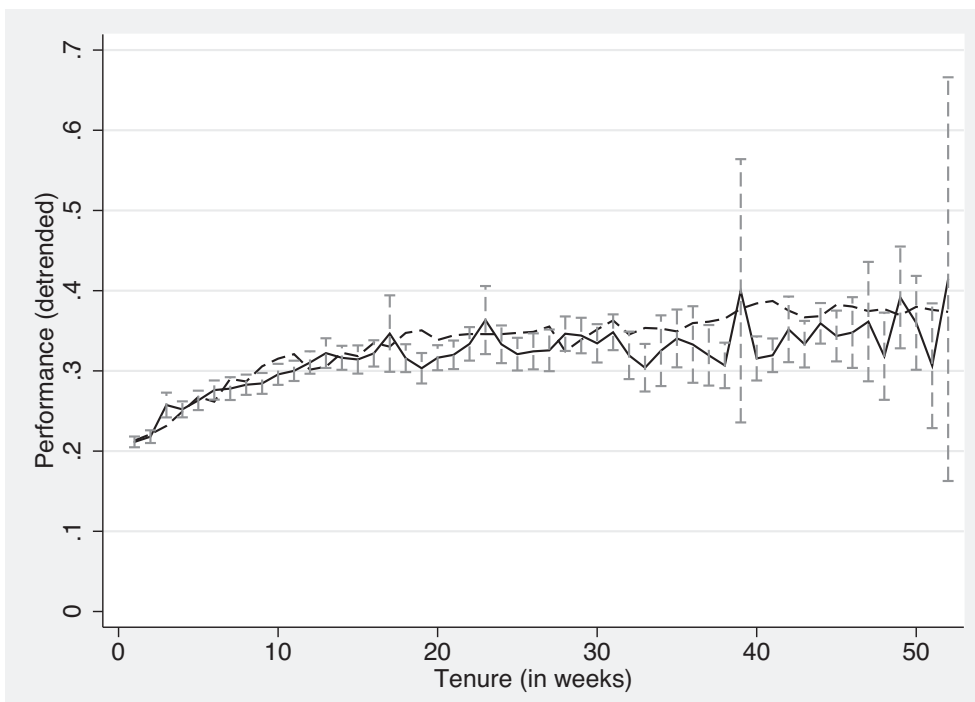

Fig. 3. Tenure-performance profiles for new hires in teams with tenure above and below the median, respectively. Note: The solid line shows the mean of $y_{i, t}$ by tenure for agents in teams with tenure below the median. The capped spikes show the appropriate $95 \%$ confidence intervals. The dashed line shows the same figure for agents in teams with tenure above the median. The underlying measure of performance is detrended by including week fixed effects.

Table 4

Definitions of average team tenure.

\begin{tabular}{|c|c|c|c|c|c|c|}
\hline & (1) & (2) & (3) & $(4)$ & (5) & (6) \\
\hline & \multicolumn{3}{|c|}{ Performance $\left(y_{i, t}\right)$} & \multicolumn{3}{|c|}{ Call quality $\left(y_{i, t}^{q}\right)$} \\
\hline $\log$ (tenure) & $\begin{array}{l}0.0344^{* * *} \\
(0.0035)\end{array}$ & $\begin{array}{l}0.0345^{* * *} \\
(0.0045)\end{array}$ & $\begin{array}{l}0.0345^{* * * *} \\
(0.0045)\end{array}$ & $\begin{array}{l}-0.0101 \text { ** } \\
(0.0049)\end{array}$ & $\begin{array}{l}-0.0083 \\
(0.0061)\end{array}$ & $\begin{array}{l}-0.0085 \\
(0.0061)\end{array}$ \\
\hline Average team tenure (current) & $\begin{array}{l}0.0044 \\
(0.0032)\end{array}$ & & & $\begin{array}{l}-0.0023 \\
(0.0032)\end{array}$ & & \\
\hline Average team tenure (last week) & & $\begin{array}{l}0.0034 \\
(0.0033)\end{array}$ & & & $\begin{array}{l}-0.0040 \\
(0.0033)\end{array}$ & \\
\hline Average team tenure (last month) & & & $\begin{array}{l}0.0033 \\
(0.0037)\end{array}$ & & & $\begin{array}{l}-0.0035 \\
(0.0037)\end{array}$ \\
\hline Constant & $\begin{array}{l}0.3028^{* * * *} \\
(0.0403)\end{array}$ & $\begin{array}{l}0.3228^{* * * *} \\
(0.0463)\end{array}$ & $\begin{array}{l}0.4052^{* * * *} \\
(0.0494)\end{array}$ & $\begin{array}{l}0.7822^{* * * *} \\
(0.1024)\end{array}$ & $\begin{array}{l}0.5906^{* * * *} \\
(0.0480)\end{array}$ & $\begin{array}{l}0.7212^{* * * *} \\
(0.0571)\end{array}$ \\
\hline$R^{2}$ & 0.313 & 0.283 & 0.279 & 0.335 & 0.335 & 0.335 \\
\hline Observations & 5551 & 5323 & 5280 & 4069 & 3927 & 3887 \\
\hline Number of agents & 228 & 228 & 228 & 196 & 194 & 194 \\
\hline
\end{tabular}

Note: ${ }^{*} p<0.10,{ }^{* *} p<0.05,{ }^{* * *} p<0.01$. Dependent variable: $y_{i, t}$ (Columns (1)-(3)); $y_{i, t}^{q}$ (Columns (4)-(6)). All regressions are estimated using all new hires. Average peer tenure is defined as the average tenure of an agent's peers. Standard errors are clustered at the agent level. All regressions include week fixed effects, team fixed effects, and control variables (working hours, cumulated training hours, gender, and age).

higher tenure have experienced a steeper tenure-performance profile than agents working in teams with lower peer tenure, suggesting that they benefit from peers with higher tenure, e.g. due to learning. ${ }^{11}$

To shed more light on the question from which peers newly hired agents might learn, we estimate the effect of $\log ($ tenure) on performance by the difference between an agent's own tenure and peer tenure, while controlling for the agent's own tenure. The dashed (horizontal) line in Fig. 4 shows our baseline estimate of the tenure-performance profile (cf. Column (6) of Table 2). The solid line shows the point estimates of tenure-performance profiles by the distance between an agent's tenure and average team tenure. The figure shows that agents who are in teams with similar tenure as their peers have a tenure-performance profile estimate that is slightly lower than the benchmark. In addition, the point estimate of the tenureperformance profile is higher than the benchmark estimate if peer tenure is at least 11 months greater than own tenure; i.e. the solid line crosses the dashed line at about 11 months. Though most point estimates are not significantly different from the baseline estimate, this result suggests that performance can already increase when working with only slightly more experienced peers.

11 This is tested based on a $t$-test for equality of the estimated $\log$ (tenure)-coefficients in both regressions. 
Table 5

The effect of peers' tenure on own performance.

\begin{tabular}{|c|c|c|c|c|c|c|c|c|}
\hline \multirow{3}{*}{$\begin{array}{l}\text { Tenure } \\
\text { Peer tenure }\end{array}$} & $(1)$ & $(2)$ & (3) & (4) & (5) & (6) & $(7)$ & $(8)$ \\
\hline & \multicolumn{2}{|c|}{$\leq 3$ months } & \multicolumn{2}{|c|}{$\leq 6$ months } & \multicolumn{2}{|c|}{$\leq 9$ months } & \multicolumn{2}{|c|}{$\leq 12$ months } \\
\hline & Low & High & Low & High & Low & High & Low & High \\
\hline $\log$ (tenure) & $\begin{array}{l}0.0269^{* * *} \\
(0.0054)\end{array}$ & $\begin{array}{l}0.0450^{* * *} \\
(0.0051)\end{array}$ & $\begin{array}{l}0.0315^{* * *} \\
(0.0050)\end{array}$ & $\begin{array}{l}0.0381^{* * *} \\
(0.0053)\end{array}$ & $\begin{array}{l}0.0317^{* * *} \\
(0.0050)\end{array}$ & $\begin{array}{l}0.0329^{* * *} \\
(0.0055)\end{array}$ & $\begin{array}{l}0.0325^{* * *} \\
(0.0050)\end{array}$ & $\begin{array}{l}0.0379^{* * *} \\
(0.0051)\end{array}$ \\
\hline Team turnover & $\begin{array}{l}0.1079 \\
(0.1303)\end{array}$ & $\begin{array}{l}-0.0564 \\
(0.0599)\end{array}$ & $\begin{array}{l}-0.0090 \\
(0.0785)\end{array}$ & $\begin{array}{l}-0.1928^{* *} \\
(0.0775)\end{array}$ & $\begin{array}{l}0.0196 \\
(0.0818)\end{array}$ & $\begin{array}{l}-0.1753^{* *} \\
(0.0824)\end{array}$ & $\begin{array}{l}-0.0535 \\
(0.0813)\end{array}$ & $\begin{array}{l}-0.1295 \\
(0.0953)\end{array}$ \\
\hline Constant & $\begin{array}{l}0.3245^{* * * *} \\
(0.0332)\end{array}$ & $\begin{array}{l}0.6015^{* * *} \\
(0.0878)\end{array}$ & $\begin{array}{l}0.3791^{* * * *} \\
(0.0492)\end{array}$ & $\begin{array}{l}0.4625^{* * *} \\
(0.0540)\end{array}$ & $\begin{array}{l}0.3427^{* * *} \\
(0.0446)\end{array}$ & $\begin{array}{l}0.3128^{* * *} \\
(0.0639)\end{array}$ & $\begin{array}{l}0.3551^{* * *} \\
(0.0325)\end{array}$ & $\begin{array}{l}0.3741^{* * * *} \\
(0.0813)\end{array}$ \\
\hline$R^{2}$ & 0.390 & 0.432 & 0.337 & 0.349 & 0.313 & 0.335 & 0.316 & 0.304 \\
\hline Observations & 1253 & 1175 & 2318 & 2222 & 2864 & 2810 & 3310 & 3316 \\
\hline Number of agents & 179 & 173 & 208 & 197 & 217 & 179 & 238 & 190 \\
\hline
\end{tabular}

Note: ${ }^{*} p<0.10,{ }^{* *} p<0.05,{ }^{* * *} p<0.01$. Dependent variable: $y_{i, t}$. All regressions are estimated using all new hires. The sample is restricted to agents with a maximum tenure 3, 6, 9, and 12 months, respectively. Low (high) peer tenure is defined as peer tenure below (above) the median peer tenure in the estimation sample analyzed. Team turnover is defined at the team level and is calculated as the average number of agents leaving a team divided by the number of agents working in a team. Standard errors are clustered at the agent level. All regressions include week fixed effects, team fixed effects, and control variables (working hours, cumulated training hours, gender, and age).

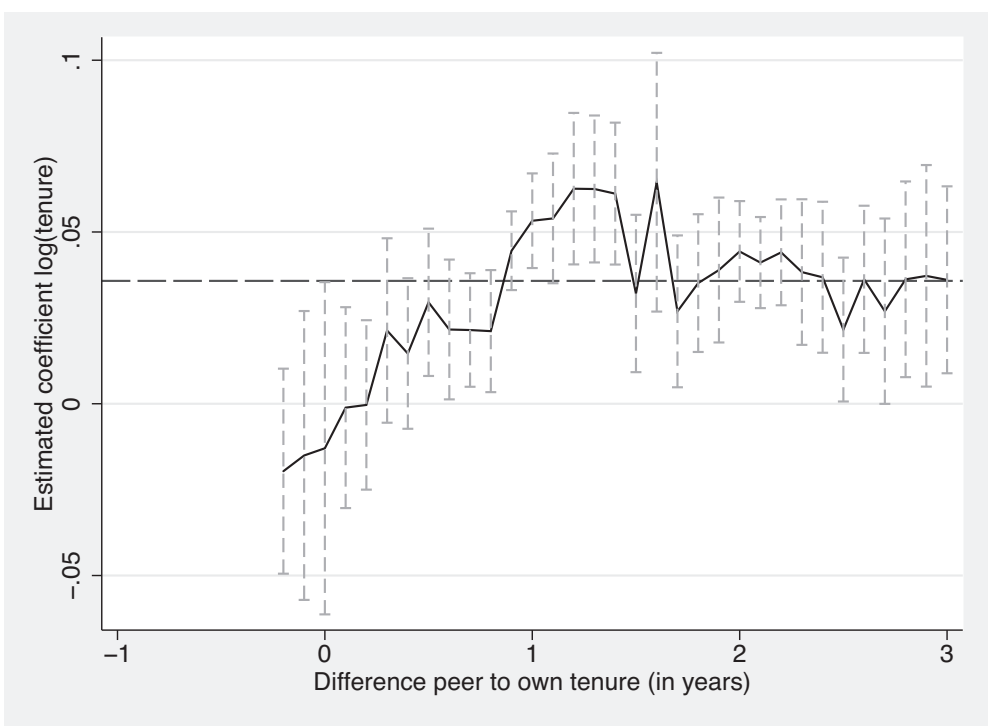

Fig. 4. Tenure-performance estimates related to differences between a worker's peers' and their own tenure. Note: The solid line show the estimated tenure-performance profiles ( bet $_{1}$ from Eq. (3)) separately for observations with the given difference (in years) from workers' own tenure to average peer tenure. The capped spikes indicate the appropriate $95 \%$ confidence intervals. The long-dashed horizontal line shows the average.

A potential concern about the estimation of peer tenure on the tenure-performance profile is the potential self-selection of agents with specific unobservable characteristics into teams. In this study, we use variation in peer composition to identify the estimation of peer effects. To credibly argue that the variation of newly hired agents to teams is random, two conditions need to be met. First, starting agents need to be randomly assigned to the existing teams. Second, there should be no selection of workers to particular working hours or shifts. If one of these assignments is not random, for example, due to the team leader's involvement, the estimated peer effect will be biased upward.

We argue that in our analysis potential biases due to any remaining selection into teams can be neglected because team leaders are not involved in the selection of newly hired agents into teams. Newly hired agents are assigned by general management to teams with vacancies. In addition, it is difficult for agents to select themselves into the same hours as particular peers. Agents must be available for scheduling during the opening hours of the call center and must state their preferences for particular hours four weeks prior. Based on both agents' preferences and expected customer demand, general management assigns agents to particular shifts without taking the team assignment into consideration. As a result, both the composition of agents at each point in time and weekly team composition change frequently. Since scheduling is done for the entire department and not for individual teams, there is no room for strategic planning within teams. Therefore, there is no reason to expect that spurious correlation drives our estimation of peer effects. 
Table 6

Selection of new agents to peers.

\begin{tabular}{|c|c|c|c|c|c|c|c|c|}
\hline & (1) & $(2)$ & (3) & $(4)$ & (5) & $(6)$ & $(7)$ & $(8)$ \\
\hline & Age & & Education & & \multicolumn{2}{|c|}{ Previous experience } & Gender & \\
\hline Average peer age & $\begin{array}{l}-0.1193 \\
(0.1468)\end{array}$ & $\begin{array}{l}-0.1326 \\
(0.1906)\end{array}$ & & & & & & \\
\hline Average peer education & & & $\begin{array}{l}-0.5684 \\
(0.5018)\end{array}$ & $\begin{array}{l}-0.5624 \\
(0.5020)\end{array}$ & & & & \\
\hline Average peer prior experience & & & & & $\begin{array}{l}-3.6501 \\
(2.6312)\end{array}$ & $\begin{array}{l}-2.1165 \\
(3.8346)\end{array}$ & & \\
\hline Average peer gender & & & & & & & $\begin{array}{l}-1.1431 \\
(1.2243)\end{array}$ & $\begin{array}{l}-1.1725 \\
(1.2125)\end{array}$ \\
\hline Average peer tenure & & $\begin{array}{l}0.0724 \\
(0.6894)\end{array}$ & & $\begin{array}{l}-0.0416 \\
(0.1120)\end{array}$ & & $\begin{array}{l}1.1471^{* * * *} \\
(0.3698)\end{array}$ & & $\begin{array}{l}0.0588 \\
(0.0969)\end{array}$ \\
\hline Constant & $\begin{array}{l}27.0034^{* * * *} \\
(4.4236)\end{array}$ & $\begin{array}{l}27.2173^{* * *} \\
(4.7982)\end{array}$ & $\begin{array}{l}2.8842^{* * * *} \\
(0.7806)\end{array}$ & $\begin{array}{l}2.7826^{* *} \\
(1.2227)\end{array}$ & $\begin{array}{l}1.5131 \\
(1.1014)\end{array}$ & $\begin{array}{l}-0.4780 \\
(1.7690)\end{array}$ & $\begin{array}{l}-0.5800^{* *} \\
(0.2795)\end{array}$ & $\begin{array}{l}-0.6849^{* *} \\
(0.3151)\end{array}$ \\
\hline$R^{2}$ & 0.078 & 0.078 & 0.299 & 0.302 & & & & \\
\hline Pseudo $R^{2}$ & & & & & 0.087 & 0.290 & 0.074 & 0.074 \\
\hline Observations & 254 & 254 & 60 & 60 & 46 & 46 & 274 & 274 \\
\hline
\end{tabular}

Note: ${ }^{*} p<0.10,{ }^{* *} p<0.05,{ }^{* * *} p<0.01$. The table shows the results of a regression of average characteristics (age, completed education, gender) of new hires' peers on new hires' characteristics. Information on age and gender is taken from the firm's personnel records, information on completed education is taken from a employee survey conducted in March to May 2009. Completed education is measured as low, medium, and high education. Previous experience is a dummy which is 1 if an agent stated to have worked in a call center prior to his current job. Columns (1)-(4) are estimated using ordinary least squares, Columns (5)-(8) are estimated using probit estimation. All standard errors are clustered at the team level. All regressions include team fixed effects.

To provide additional evidence against the argument that peers are endogenously selected to each other, we provide three tests. First, one concern of the peer tenure estimates in Column (1) of Table 5 and the difference in the tenure estimate of Columns (2) and (3) is potential non-random selection into teams. All regressions so far control for team-specific fixed effects which should eliminate any unobserved heterogeneity that is constant in teams. We explore endogeneity of our estimation results by augmenting Eq. (5) by a measure of team turnover. Higher turnover, which should result in more vacancies in a team, might be related with particularly low performance of agents. Although high-tenure teams seem to have smaller point estimates of the variable team turnover than low-tenure teams, this effect is only significantly different from zero in two regressions (Columns (4) and (6)).

Second, Table 6 provides further evidence against non-random selection based on observable characteristics. Following Sacerdote (2001), we estimate the effect of average peer characteristics on various characteristics of new hires: age, level of education, previous experience in call centers, and gender. The table shows the regression coefficients of a regression of a new hire's characteristics on the average peer characteristics at the time an agent starts in the team. Neither average peer characteristics nor peer tenure are significantly related to new hires' observable characteristics. Only the estimated coefficient for average peer tenure on previous experience of new hires is significantly different from zero. This suggests that, based on these observable characteristics, there is no evidence for selection of similar individuals into teams, and almost no selection with respect to a team's tenure level.

Third, we use a placebo test in which we assigned agents to randomly chosen peers with similar team size. This procedure was repeated 1000 times. Fig. 5 shows the histogram of 1000 estimated coefficients for the variable peer tenure $\left(\widehat{\beta}_{3}\right)$. The estimates are centered around zero and are significantly different from zero in $7.4 \%$ out of 1000 cases. Furthermore, only $5.7 \%$ of the estimates are larger than the estimate of 0.0044 in Column (1) in Table 4 . This provides further evidence against the criticism that peer estimates are the results of spurious correlation and suggests that our estimates of peer tenure are precisely estimated.

\subsection{Investments in on-the-job learning}

Our interpretation of the shape of the tenure-performance profile is that it reflects an agent's stock of skills. The tenureperformance profile can thus be used to estimate the size of the firm's investment in on-the-job learning, G. For a vacant position, the firm can either appoint an experienced agent or hire an inexperienced agent with zero tenure. The firm invests in on-the-job learning of new hires because it accepts low performance in the first months, compared to a situation where it would employ a fully experienced agent. We therefore assume that an inexperienced agent starts with performance $y_{d=1}$ in the first working week $d=1$ and then exhibits the tenure-performance profile estimated by Eq. (3) until the agent can perform at the level of an experienced agent after $D$ weeks of tenure, $y_{d=D}$.

To calculate the firm's investments in newly hired workers before they achieve the same level of performance as more experienced agents, we use the original measure of average handling time $a h t_{d}$. After calculating the difference between the performance of experienced agents and agents who are not yet experienced, $a h t_{d=D}-a h t_{d} \forall d=1, \ldots, D-1$, we can multiply 


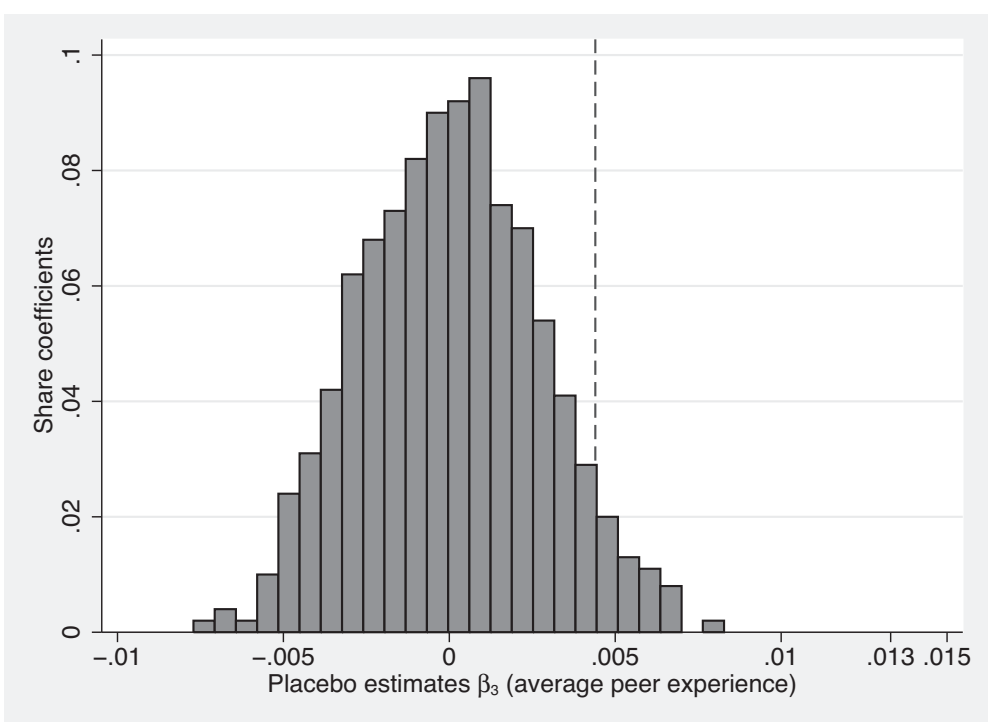

Fig. 5. Distribution of estimated $\beta_{3}$ in placebo team assignments. Note: The histogram shows the distribution of 1000 estimated coefficients of the peer tenure variable $\left(\widehat{\beta}_{3}\right.$ from Eq. (5)). Each of the 1000 estimated coefficients is based on a randomly drawn team assignment and a measure of average team tenure which is calculated according to Eq. (4). The dashed vertical line shows the baseline estimate from Table $4\left(\widehat{\beta}_{3}=0.0044\right)$.

this difference in average handling time by the average number of calls an experienced agent handles in one week, $c_{d}$. We interpret the sum $G$

$$
G=\sum_{d=1}^{D-1}\left(a h t_{d=D}-a h t_{d}\right) \cdot c_{d}
$$

as the human capital investment in untrained workers during their first year. Since the wage profile is relatively flat for workers in their first year, the firm implicitly needs to invest $G$ number of hours of on-the-job learning when hiring a new worker, as opposed to the alternative of having a worker with at least one year of tenure for the same task. When using the non-parametric estimate of the tenure-performance profile (cf. Fig. 1), we find that $127 \mathrm{~h}$ of on-the-job learning are required before a new hire has the same productivity as an experienced agent.

This calculation also allows us to point out the value of peer tenure for a new hire. When calculating $G$ for agents in experienced and inexperienced teams (cf. Fig. 3), we find considerable differences: Agents in less experienced teams need $160 \mathrm{~h}$ of investments in on-the-job learning, while agents in more experienced teams need only $102 \mathrm{~h}$. This suggests that by placing new workers in experienced teams reduces the investments in on-the-job learning by $36 \%$. The difference between agents placed in experienced teams and those who are placed in inexperienced teams seems relatively large, given the modest effect of peer tenure on learning. The numbers, however, are calculated cumulatively over the first year of tenure. Over the course of the first year, workers work an average of $1090 \mathrm{~h}$.

Data on formal training programs provided by the firm show that new hires spend on average of $124 \mathrm{~h}$ on formal training programs paid by the firm in the first year of their employment, most of which is starter training before the first working week. This shows that the firm's investment in on-the-job learning for new hires $(127 \mathrm{~h})$ is similar to the investments in formal training.

\section{Robustness checks and additional results}

\subsection{Working hours and the shape of tenure-performance profiles}

There is substantial within- and between-worker heterogeneity in the working hours at the call center we analyze. If on-the-job learning is related to the actual number of hours worked, this heterogeneity may lead to differences in the shape of the estimated tenure-performance profiles, depending on the number of working hours. Since we measure tenure in calendar weeks, part-timers build up less tenure in a week than those who work full-time and will therefore have lower tenure-performance profiles.

To assess this possible heterogeneity, we re-estimate the tenure-performance profiles for two different groups of workers, part-time workers and full-time workers. Table 7 shows that part-timers have significantly lower tenure-performance profiles compared to those of full-time agents. Though the differences in the estimated tenure-performance profiles might also be the result of selection of certain types of individuals into part-time and full-time jobs, this result suggests that the 
Table 7

Tenure-performance profiles for part-time and full-time workers.

\begin{tabular}{lll}
\hline & $(1)$ & $(2)$ \\
& Part-time & Full-time \\
& $\log ($ tenure $)$ & $\log$ (tenure) \\
\hline $\log ($ tenure $)$ & $0.0289^{* * *}$ & $0.0412^{* * *}$ \\
Constant & $(0.004)$ & $(0.004)$ \\
& $0.4176^{* * *}$ & $0.3734^{* * * *}$ \\
$R^{2}$ & $(0.045)$ & $(0.035)$ \\
Observations & 0.347 & 0.380 \\
Number of agents & 2794 & 2757 \\
\hline
\end{tabular}

Note: ${ }^{*} p<0.10,{ }^{* *} p<0.05,{ }^{* * *} p<0.01$. Dependent variable: $y_{i, t}$. All standard errors are clustered at the agent level. All regressions are estimated using all new hires. Part-time and full-time are defined as, respectively, below- and above-the median number of working hours over the first year of employment. All regressions include week fixed effects, team fixed effects, and control variables (working hours, cumulated training hours, gender, and age).

number of working hours determines the tenure-performance profiles, especially for jobs dominated by part-time workers. The result also strongly suggests that performance does increase over time due to the accumulation of human capital by learning on the job.

\subsection{Trade-off between the quantity and quality of calls}

The performance variable used in this study, average handling time, is a measure of quantitative performance. However, there may be a trade-off between the quantity and quality of calls, as shorter calls may not always be satisfactory for customers, e.g. because problems are not entirely solved. Following De Grip and Sauermann (2012), we therefore use additional information to estimate the effect of tenure on the quality of calls. First, we use a measure that is based on the share of repeat calls to capture the quality of agents' calls. The share of repeat calls is defined as the share of customers to whom an agent spoke who call back within seven days. This measure is used by management to evaluate the quality of calls, since customers will call again if their problem is not solved. Low values of repeat calls $\left(r c_{i, t}\right)$ are interpreted as high performance. We therefore define call quality as $y_{i, t}^{q}=\left(1 / r c_{i, t} * 10\right)$. The average quality is 0.527 for new hires in their first year of employment (see Table 1). Given that this variable is available for each agent for each working week, the data allow us to create a composite measure of productivity that contains both the quantitative and qualitative dimensions of worker performance. We define this composite measure as $y_{i, t}^{\prime}$ as $y_{i, t}^{\prime}=y_{i, t} *\left(1-r c_{i, t}\right)$. The intuition of this measure is that larger shares of repeat calls $r c_{i, t}$ are interpreted as a performance penalty, since each additional percentage point in the share of repeat calls (lower quality) relates to a lower composite measure of productivity $y_{i, t}^{\prime}$.

Second, we use information from a customer satisfaction survey as an alternative measure of call quality. This survey is conducted monthly to monitor the quality provided by the departments at an aggregate level but can be linked to individual agents. Each month, 200 incoming calls are randomly selected and the customers are called for a short survey. The survey contains three outcomes related to agent quality. Customers were asked to grade the "knowledge of the agent" (Grade 1), whether the "agent understood the question" (Grade 2), and whether the agent had a "solution to the problem" (Grade 3) on a scale from one (very bad) to 10 (very good). Despite the fact that the sample size for the customer satisfaction variables is rather small, the results of this survey provide additional evidence on call quality.

Panels (a)-(c) of Fig. 6 show the tenure-performance profile for the call quality measure $\left(y_{i, t}^{q}\right)$, the composite measure $\left(y_{i, t}^{\prime}\right)$, and the customer satisfaction measure, respectively. Panel (a) of Fig. 6 shows that call quality appears to decrease in the first three months of employment and flattens thereafter. However, compared to our main performance measure, the decrease in quality over time seems to be small. For the composite measure (Panel (b)), the increase in performance therefore remains strong and significant. Panel (c) shows that little variation in customer satisfaction is explained by agent tenure.

Table 8 shows the estimation results of the relation between tenure and call quality outcome. Column (1) shows that with increasing tenure, call quality significantly decreases $(-0.011)$. A $10 \%$ increase in tenure is thus related to a decrease in call quality by $0.5 \%$ of one standard deviation in the quality measure. This suggests that, despite the fact that performance quantity improves substantially over the course of the first months, this result comes partly at the cost of slightly lower call quality. However, the results in Column (2) of Table 8 indicate a positive effect of tenure on the overall composite performance measure. The estimated coefficient of 0.024 is significantly different from zero. A $10 \%$ increase in tenure thus leads to an increase in overall performance of $3.1 \%$ of a standard deviation. This suggests that the positive performance quantity effect outweighs the negative quality effect.

Using the more specific information on call quality from the customer satisfaction survey, Columns (3)-(5) of Table 8 show no significant relation between agent tenure and the three specific aspects of customer satisfaction. Neither the agent's 
(a)

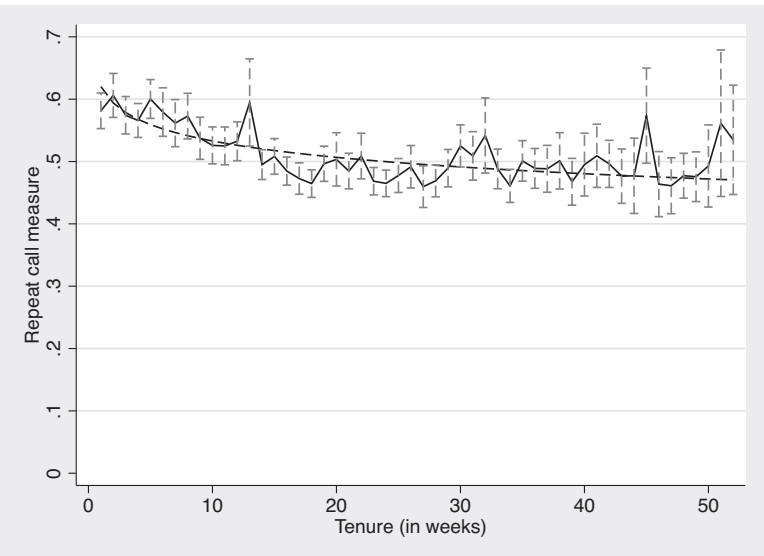

(b)

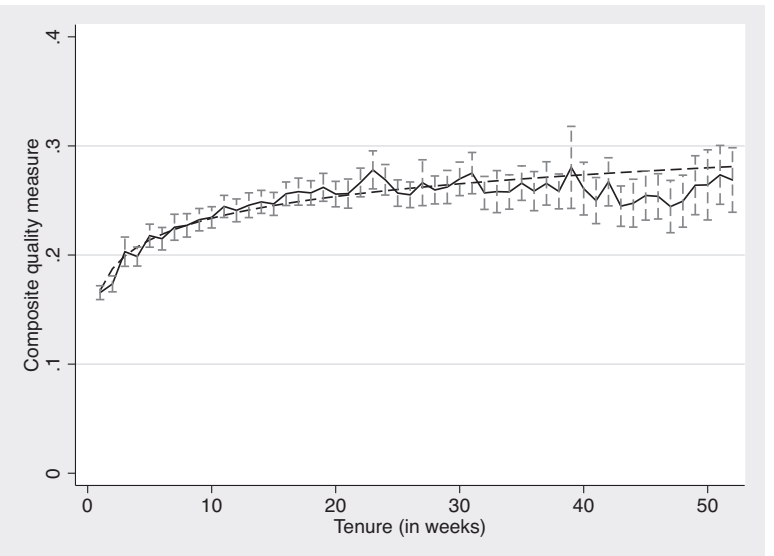

(c)

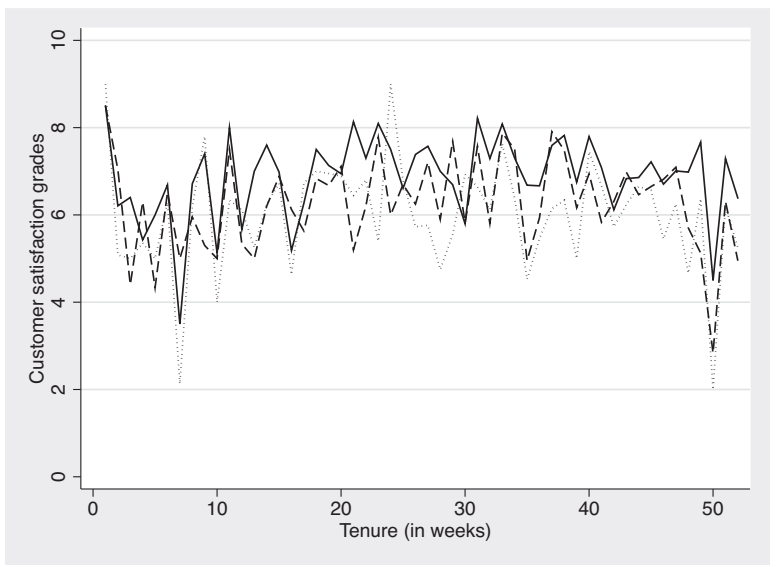

Fig. 6. Non-parametric tenure-quality profiles and composite performance profiles for new hires. Note: Panel (a) shows the tenure-performance profile for the repeat call measure and Panel (b) shows the corresponding figure for the composite performance measure. The capped spikes show the appropriate 95\% confidence intervals. The dashed line shows the predicted performance after regression of $y_{i, t}$ on log(tenure). Panel (c) shows the corresponding tenure-performance profiles for grades taken from the customer satisfaction survey. Grades are defined for "knowledge of agent" (Grade 1, solid line), "agent understood question" (Grade 2, dashed line), and "agent's solution of the problem" (Grade 3, dotted line). All grades are defined on a scale of one to 10 .

Table 8

Estimating new hires' tenure-performance profiles for call quality outcomes.

\begin{tabular}{|c|c|c|c|c|c|}
\hline & $\begin{array}{l}(1) \\
\text { Repeat calls }\end{array}$ & $\begin{array}{l}(2) \\
\text { Composite measure }\end{array}$ & $\begin{array}{l}(3) \\
\text { Grade } 1\end{array}$ & $\begin{array}{l}(4) \\
\text { Grade } 2\end{array}$ & $\begin{array}{l}(5) \\
\text { Grade } 3\end{array}$ \\
\hline $\log$ (tenure) & $\begin{array}{l}-0.0109^{* *} \\
(0.005)\end{array}$ & $\begin{array}{l}0.0240^{* * *} \\
(0.003)\end{array}$ & $\begin{array}{l}0.1188 \\
(0.252)\end{array}$ & $\begin{array}{l}0.1146 \\
(0.230)\end{array}$ & $\begin{array}{l}-0.1139 \\
(0.270)\end{array}$ \\
\hline Number of surveys & & & $\begin{array}{l}-0.0895 \\
(0.084)\end{array}$ & $\begin{array}{l}-0.1074 \\
(0.081)\end{array}$ & $\begin{array}{l}-0.0409 \\
(0.106)\end{array}$ \\
\hline Constant & $\begin{array}{l}0.7664^{* * *} \\
(0.098)\end{array}$ & $\begin{array}{l}0.3036^{* * *} \\
(0.028)\end{array}$ & $\begin{array}{l}7.4923^{* * *} \\
(0.572)\end{array}$ & $\begin{array}{l}6.7503^{* * *} \\
(1.466)\end{array}$ & $\begin{array}{l}6.6909^{* * *} \\
(0.995)\end{array}$ \\
\hline$R^{2}$ & 0.334 & 0.242 & 0.135 & 0.243 & 0.184 \\
\hline Observations & 4069 & 4069 & 321 & 321 & 301 \\
\hline Number of agents & 196 & 196 & 86 & 86 & 83 \\
\hline
\end{tabular}

Note: ${ }^{*} p<0.10,{ }^{* *} p<0.05,{ }^{* * *} p<0.01$. All regressions are estimated using all new hires. Standard errors are clustered at the agent level. Grades are defined for "knowledge of agent" (Grade 1), "agent understood question" (Grade 2), and "agent's solution of the problem" (Grade 3). All grades are defined on a scale of one to 10 . All regressions include week fixed effects, team fixed effects, and control variables (working hours, cumulated training hours, gender, and age). The number of surveys is defined as the number of customer surveys which the grades are based on. 
knowledge, the agent's understanding of the question, nor having a proper solution to the customer's problem appear to be related to the tenure of new hires.

To analyze whether peer tenure affects service quality, we repeat the analysis shown in Section 3.3 with the quality outcome $y_{i, t}^{q}$. The results shown in Table 4 show a similar pattern as with $y_{i, t}$ : the average peer tenure in the current and the previous week, and the previous month result in similar estimates, which are all not significant. In line with the estimate of new hires' own tenure on $y_{i, t}^{q}$, all estimated coefficients are negative. Different to the estimates for $y_{i, t}$, own tenure is not significantly different from zero when including lagged measures of average team tenure in the regressions on quality outcome (Columns (5) and (6) of Table 4).

\section{Conclusion}

In this paper, we analyze the tenure-performance profiles of newly hired call center agents, using unique weekly panel data from a multinational telecommunication firm's call center that contain detailed performance information at the individual level. Our results show that call agents have a very steep tenure-performance profile in the beginning of their job in the call center. This increase, however, diminishes considerably after about six months. The tenure-performance profile can very well be described by a logarithmic function. An increase in tenure of $10 \%$ leads to an increase of $4 \%$ of one standard deviation in performance. Although we find that agents leaving the call center are rather low-performers, our results are not driven by this selection.

We interpret the increase in performance during the first year of employment as learning due to the accumulation of human capital. Since the agents' task-answering customer calls-is repetitive, the highest returns to learning could be expected to occur in the beginning of the employment relationship. In our sample, agents perform $64 \%$ better after 12 months, which is comparable to related findings from other industry sectors. This learning effect is very strong in the beginning, and flattens off after about 6 months. The rather fast learning of agents may be due to the relatively low complexity of their job. In other, more complex jobs, tenure-performance profiles are likely be less steep.

Our results show that the firm's investment in on-the-job learning is substantial. The lower performance of agents before they reach the performance level of more experienced agents translates into an investment in on-the-job learning of about 127 working hours. This amount of time spent on learning on the job comes close to the firm's investments in formal training courses for new hires, which accumulate to an average of 124 working hours. However, when using data on customer satisfaction, we find evidence of a quality-quantity trade-off in the tenure-performance profile. As new hires gain tenure, the number of customers calling back within a few days after the call increases slightly, which suggests a decrease in the quality delivered to the customer. Overall, the increase in quantitative performance outweighs the decrease in quality.

Furthermore, our study is the first that shows that new hires benefit significantly from working with more experienced peers, especially during the first 3 months. We find that this effect is stronger when peers are more experienced. Agents in less experienced teams need $160 \mathrm{~h}$ of investments in on-the-job learning, while agents in more experienced teams need only $102 \mathrm{~h}$. This suggests that placing new agents in experienced teams reduces the investments in on-the-job learning by $36 \%$.

The speed of this learning process is most important for call centers and other firms which often recruit new hires because of high quit rates, but definitely it is highly relevant for all firms that employ new hires. Initial productivity of new hires is often quite low compared to that of more experienced workers as shown by various studies (Carroll et al., 1986; Kostiuk and Follmann, 1989; Jovanovic and Nyarko, 1995; Shaw and Lazear, 2008) Our findings on the impact of team composition on the speed of learning of new hires shows that firm productivity could improve when new hires are placed in teams with more experienced agents instead of forming teams of predominantly newly hired workers. This particularly holds for the first 3 months of employment.

\section{References}

Altonji, J.G., Shakotko, R.A., 1987. Do wages rise with job seniority? Rev. Econ. Stud. 54 (3), 437-459.

Angrist, J.D., 2014. The perils of peer effects. Labour Econ. 30, 98-108.

Avdic, D., Lundborg, P., Vikström, J., 2014. Learning-by-doing in a High-skill Profession When Stakes are High: Evidence From Advanced Cancer Surgery. IZA Working Paper 8099. Institute for the Study of Labor (IZA), Bonn.

Bandiera, O., Barankay, I., Rasul, I., 2010. Social incentives in the workplace. Rev. Econ. Stud. 77 (2), $417-459$.

Barron, J.M., Black, D.A., Loewenstein, M.A., 1989. Job matching and on-the-job training. J. Labor Econ. 7 (1), 1-19.

Batt, R., Doellgast, V., Kwon, H., 2006. Service management and employment systems in U.S. and Indian call centers. In: Collins, S.M., Brainard, L. (Eds.), Brookings Trade Forum 2005: Offshoring White-Collar Work-The Issues and Implications. Brookings Institution Press, Washington, D.C., pp. 335-372.

Batt, R., Holman, D., Holtgrewe, U., 2009. The globalization of service work: comparative institutional perspectives on call centers. Ind. Labor Relat. Rev. 62 (4), 453-488.

Benkard, C.L., 2000. Learning and forgetting: the dynamics of aircraft production. Am. Econ. Rev. 90 (4), $1034-1054$.

Bishop, J.H., 1989. On-the-job Training of New Hires. CAHRS Working Paper Series 401, Cornell University, School of Industrial and Labor Relations. Center for Advanced Human Resource Studies, Ithaca, NY.

Carroll, V.P., Lee, H.L., Rao, A.G., 1986. Implications of salesforce productivity heterogeneity and demotivation: a navy recruiter case study. Manage. Sci. 32 (11), 1371-1388.

Castilla, E.J., 2005. Social networks and employee performance in a call centre. Am. J. Sociol. 110 (5), $1243-1283$.

De Grip, A., Sauermann, J., 2012. The effects of training on own and co-worker productivity: evidence from a field experiment. Econ. J. 122 (560), 376-399.

Destré, G., Lévy-Garboua, L., Sollogoub, M., 2008. Learning from experience or learning from others? Inferring informal training from a human capital earnings function with matched employer-employee data. J. Socio-Econ. 37 (3), 919-938. 
Falk, A., Ichino, A., 2006. Clean evidence on peer effects. J. Labor Econ. 24 (1), 39-58.

Flabbi, L., Ichino, A., 2001. Productivity, seniority and wages: new evidence from personnel data. Labour Econ. 8 (3), $359-387$.

Guryan, J., Kroft, K., Notowidigdo, M., 2009. Peer effects in the workplace: Evidence from random groupings in professional golf tournaments. Am. Econ. J.: Appl. Econ. 1 (4), 34-68.

Herbst, D., Mas, A., 2015. Peer effects on worker output in the laboratory generalize to the field. Science 350 (6260), 545-549.

Jackson, C.K., Bruegmann, E., 2009. Teaching students and teaching each other: the importance of peer learning for teachers. Am. Econ. J.: Appl. Econ. 1 (4), $85-108$.

Jovanovic, B., Nyarko, Y., 1995. A Bayesian learning model fitted to a variety of empirical learning curves. In: Brookings Papers on Economic Activity. Microeconomics 1995., pp. 247-305

Kostiuk, P.F., Follmann, D.A., 1989. Learning curves, personal characteristics, and job performance. J. Labor Econ. 7 (2), $129-146$.

Levitt, S.D., List, J.A., Syverson, C., 2013. Toward an understanding of learning by doing: evidence from an automobile assembly plant. J. Polit. Econ. 121 (4), 643-681.

Liu, X., Batt, R., 2007. The economic pay-offs to informal training: evidence from routine service work. Ind. Labor Relat. Rev. 61 (1), 75-89.

Mas, A., Moretti, E., 2009. Peers at work. Am. Econ. Rev. 99 (1), 112-145.

OECD, 2013. OECD Skills Outlook 2013: First Results from the Survey of Adult Skills. OECD Publishing.

Rosen, S., 1972. Learning and experience in the labor market. J. Hum. Resour. 7 (3), 326-342.

Sacerdote, B., 2001. Peer effects with random assignment: results for Dartmouth roommates. Q. J. Econ. 116 (2), $681-704$.

Shaw, K., Lazear, E.P., 2008. Tenure and output. Labour Econ. 15 (4), 705-724.

Thompson, P., 2001. How much did the liberty shipbuilders learn? New evidence for an old case study. J. Polit. Econ. 109 (1), $103-137$. 